\title{
A rare cause of pneumomediastinum and subcutaneous emphysema: Tooth extraction
}

\author{
Pnömomediastinum ve subkutan amfizemin nadir bir nedeni: Diş çekimi

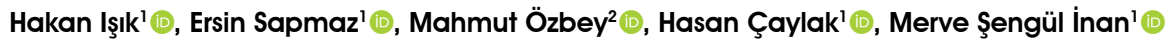 \\ Institution where the research was done: \\ Gülhane Training and Research Hospital, Ankara, Turkey \\ Author Affiliations: \\ 'Department of Thoracic Surgery, Gülhane Training and Research Hospital, Ankara, Turkey \\ 2Department of Thoracic Surgery, Erol Olcok Training and Research Hospital, Çorum, Turkey
}

\begin{abstract}
Pneumomediastinum is defined as the presence of free air between mediastinal structures. Although most of the cases occur spontaneously or due to traumatic reasons, they may rarely be observed after dental procedures. It is considered that the use of high speed air turbin drill during dental procedures might cause mediastinal emphysema. High-pressured air dissects the soft tissues starting from the impaired dento-alveolar membrane and reaches the mediastinum. Contaminated fluid and air can reach the mediastinum after the deterioration of the intraoral barrier and may result in highly mortal descending mediastinitis. In this article, we present a 53-year-old female patient of pneumomediastinum developing after tooth extraction using high-speed air turbine.
\end{abstract}

Keywords: Pneumomediastinum, subcutaneous emphysema, tooth extraction.

Pneumomediastinum $(\mathrm{PM})$ is a rare clinical entity defined as the presence of free air between mediastinal structures. Although the symptoms and findings of subcutaneous emphysema were described by Laennec in 1819, the definition of PM was first introduced to the medical literature by Louis Hamman in 1939. ${ }^{[1]}$ The release of free air through the rupture of the alveoli is responsible for the development of spontaneous PM. The majority of the PM cases are reported after blunt and

\section{$\ddot{O} Z$}

Pnömomediastinum mediastinal yapılar arasında serbest havanın varlığı olarak tanımlanır. Olguların çoğu spontan şekilde veya travmatik nedenlerle ortaya çıksa da dental işlemlerden sonra da nadiren görülebilir. Dental işlemler sırasında yüksek hızlı hava türbini matkabı kullanımının mediastinal amfizeme neden olabileceği düşünülmektedir. Yüksek basınçlı hava bozulmuş dento-alveolar membrandan başlayarak yumuşak dokuları diseke eder ve mediastene ulaşır. Kontamine sivi ve hava intraoral bariyerin bozulmasindan sonra mediastene ulaşabilir ve son derece ölümcül desenden mediastinite yol açabilir. Bu yazıda, yüksek hızlı hava türbininin kullanıldığ 1 diş çekimi sonrası pnömomediastinum gelişen 53 yaşında bir kadın hasta sunuldu.

Anahtar sözcükler: Pnömomediastinum, subkutan amfizem, diş çekimi.

penetrating traumas, tracheostomy, endoscopy, head and neck surgery, cardiac surgery, and high-pressure mechanical ventilation in the literature, while the number of cases reported after tooth extraction is extremely low. ${ }^{[2]}$ Use of high-speed air turbine drill (HSATD) during dental procedures is believed to be the reason of PM seen after tooth extraction. ${ }^{[3]}$ In this article, we present a case of PM occurring after a dental procedure, which was thought to be an allergic reaction.

Received: July 26, 2019 Accepted: October 20, 2019 Published online: April 22, 2020

Correspondence: Hakan Işık, MD. Gülhane Eğitim ve Araştırma Hastanesi Göğüs Cerrahisi Kliniği, 06010 Keçiören, Ankara, Türkiye. Tel: +90 312 - 3045188 e-mail: hakan_hj@hotmail.com 


\section{CASE REPORT}

A 53-year-old female patient admitted to the emergency service with complaints of right neck swelling, chest pain, and dyspnea after a dental operation of the lower right third molar tooth with the use of a HSATD. She had no history of cardiopulmonary disease previously. Her dental operation was performed 12 hours before admission

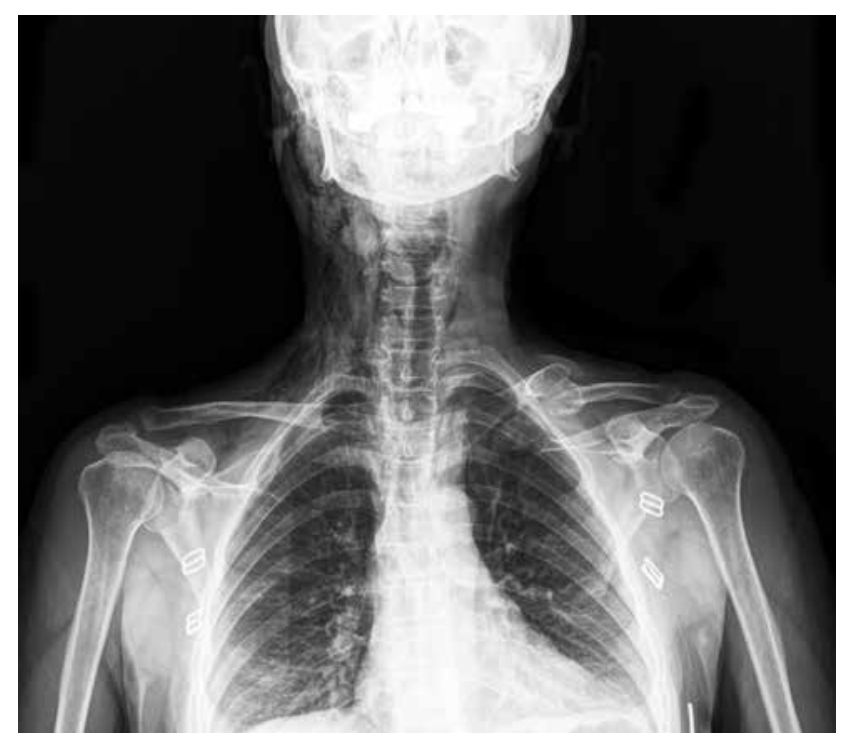

Figure 1. Posteroanterior chest/cervical X-ray showing subcutaneous emphysema at cervical and supraclavicular area.

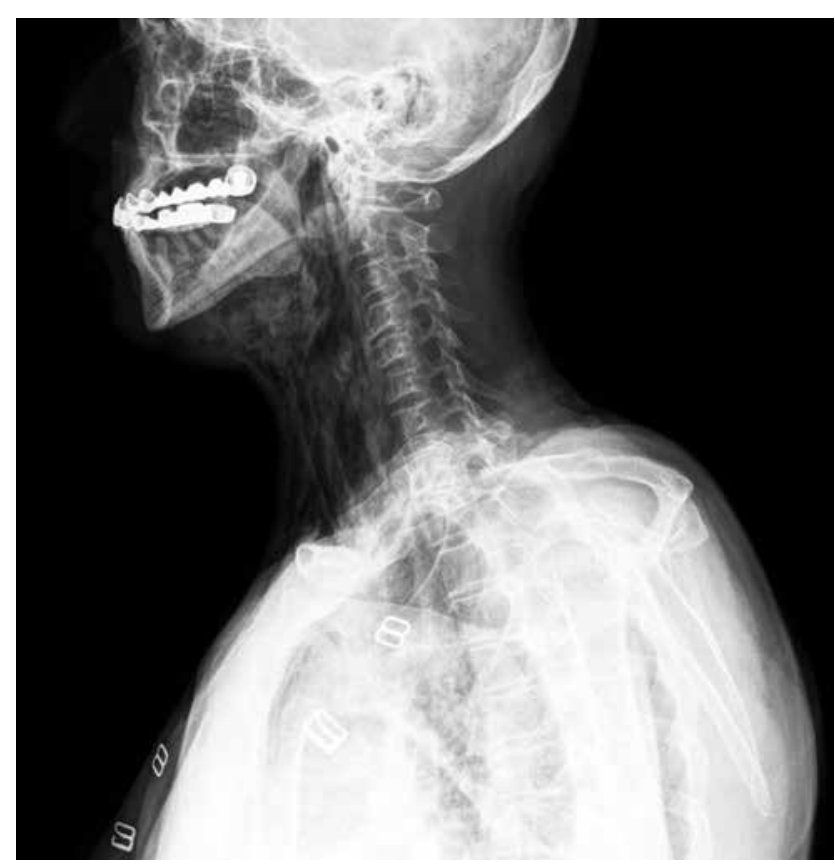

Figure 2. Lateral cervical X-ray showing subcutaneous emphysema. to the emergency service. Initially, the dentist suspected that she was allergic to the drug and injected dexamethasone and antihistamines to avoid anaphylactic reaction. In the first evaluation of the emergency service, heart rate was 78 beats/min, arterial blood pressure was $120 / 80 \mathrm{mmHg}$, body temperature was $36.2^{\circ} \mathrm{C}$, and peripheral oxygen saturation was $96 \%$ in the room air. Physical examination revealed swelling in the right facial region. Crepitations were identified on the right side of the face, in the neck, and the right supraclavicular area by palpation. Laboratory analysis showed that white blood cell count was $6800 / \mathrm{mm}^{3}$, highsensitivity C-reactive protein (hs-CRP) was $72.1 \mathrm{mg} / \mathrm{dL}$, and procalcitonin was $0.04 \mathrm{ng} / \mathrm{dL}$. Biochemical values were normal except hs-CRP. Posteroanterior/lateral chest and two-sided cervical $\mathrm{X}$-rays showed subcutaneous emphysema in the right supraclavicular area (Figures 1 and 2). A written informed consent was obtained from the patient.

Computed tomography (CT) revealed common subcutaneous emphysema in the right half of the neck and retropharyngeal areas. In the mediastinum, there was subcutaneous emphysema extending from the neck to the anterior wall of the chest, consistent with PM (Figure 3). In order to avoid mediastinitis, piperacillin-tazobactam was initiated
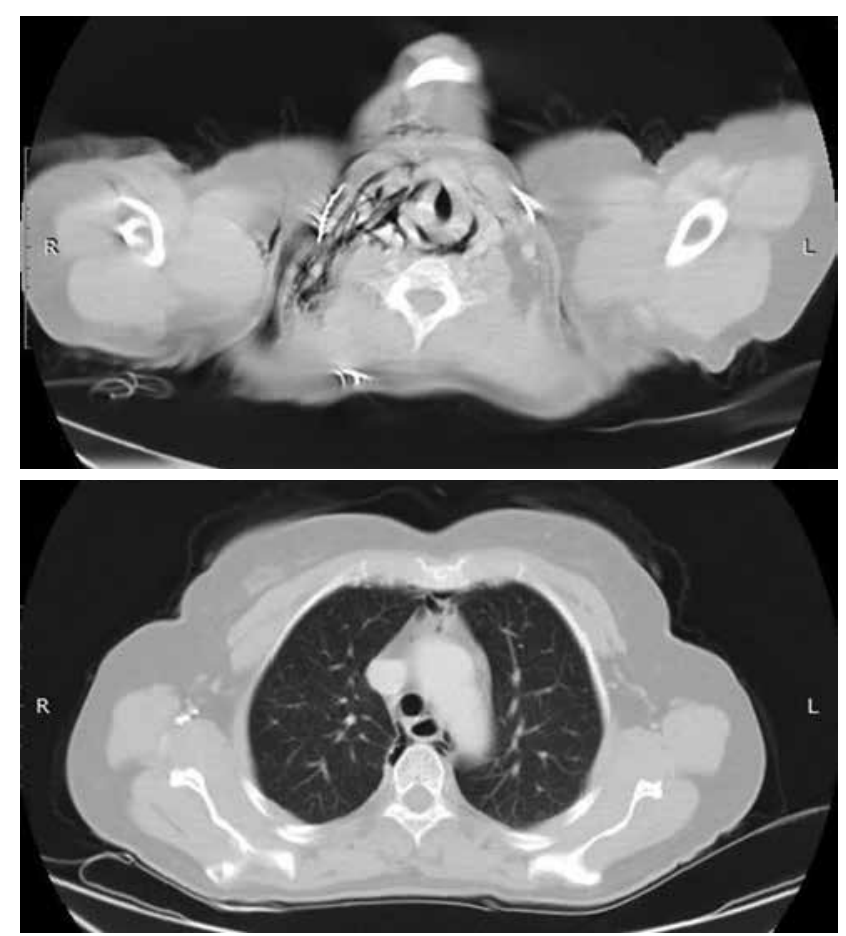

Figure 3. Thoracic computed tomography images showing free air within mediastinum and cervical areas. 


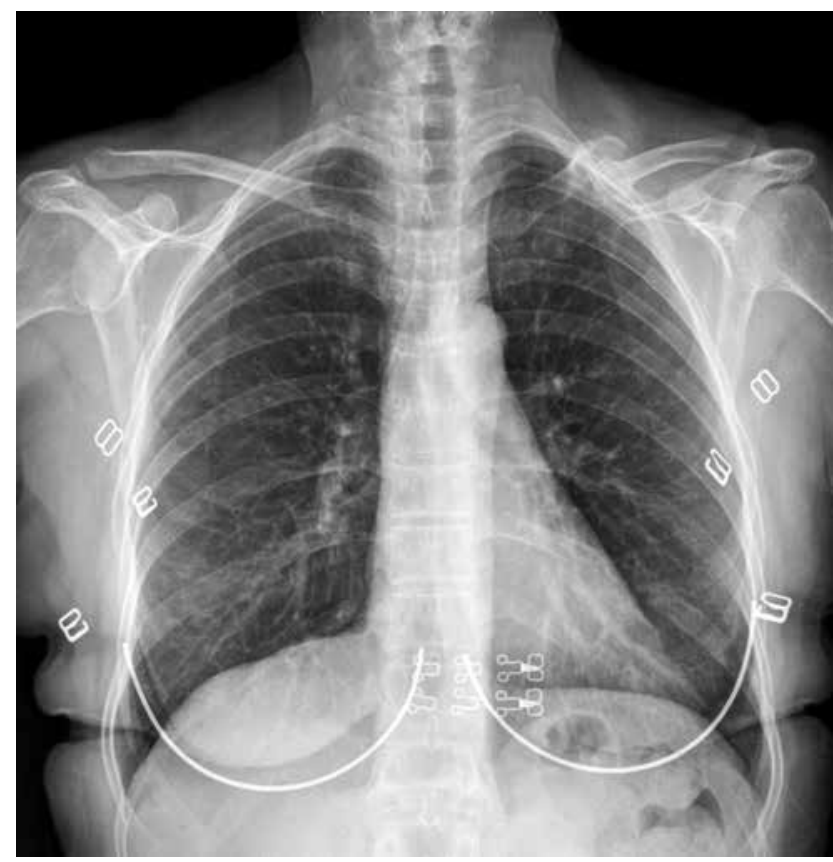

Figure 4. Posteroanterior chest X-ray at seventh day. Radiologic findings were almost completely regressed.

prophylactically with the recommendation of the department of infectious diseases. The patient was followed radiographically with chest $\mathrm{X}$-ray and infection parameters were studied daily in the laboratory analysis. On the seventh day of admission to the hospital, neck and thorax CT were performed. The radiologic findings were almost completely regressed (Figures 4 and 5). During the follow-up and treatment, there was no negative development in favor of mediastinitis (hs-CRP level was normal) and the patient was discharged on the seventh day.

\section{DISCUSSION}

Pneumomediastinum is a condition characterized by the presence of free air in mediastinum and it is very rare after dental surgical procedures. In a review published by Yang et al..$^{[4]}$ in 2006, thirteen articles were studied for the clinical findings emerging after the treatment of lower teeth. It was concluded that the majority of PM cases occurred due to procedures performed on the lower third molar teeth.

High-speed air turbine drill is considered to be responsible for subcutaneous emphysema and PM after dental procedures. High-speed air turbine drill is used to remove debris formed during the procedure and to reduce the increased heat. This method provides good view by removing residuals while preventing the heat on the tooth surface from rising above $43^{\circ} \mathrm{C}$,

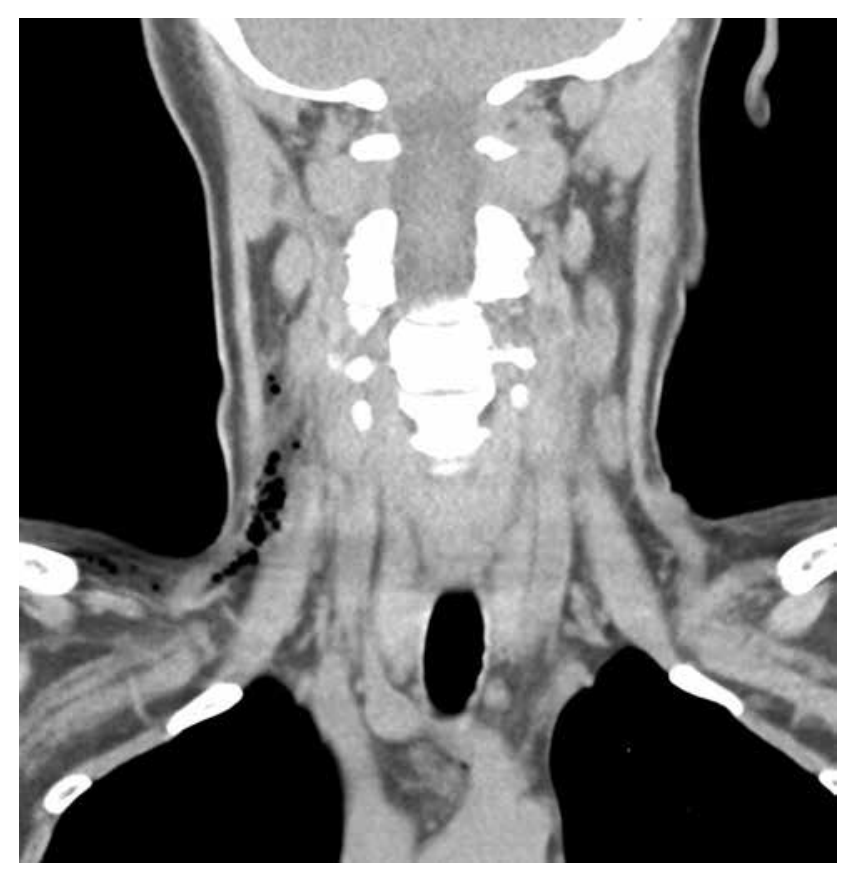

Figure 5. Computed tomography scan of cervico-thoracic area shows slightly remaining subcutaneous emphysema.

a fatal value for bone tissue. When the impairment of the intraoral barrier creates a path that the air can follow, the effect of the high pressure can easily pass through this air-forming defect. ${ }^{[5]}$ Compressed air is believed to reach the dento-alveolar membrane, which is damaged during the procedure, and then the neck and mediastinum through sublingual and retropharyngeal cavities. ${ }^{[4,6]}$ The use of a HSATD during tooth extraction is not a routine practice and HSATD is used in case of cleaning the remaining debris after tooth breakage, as in our case.

Contaminated fluid and air can reach the mediastinum after the deterioration of the intraoral barrier and may result in highly mortal descending mediastinitis. The most important step in the management of PM is a correct diagnosis. Pneumomediastinum should be kept in mind if head and neck swelling, dysphonia and crepitation occur during or after dental procedures. Complications such as hematoma, allergic reactions, and angioedema that may be present in similar findings should be considered in the differential diagnosis of mediastinal emphysema. A careful physical examination may provide sufficient information for accurate diagnosis. In our case, sudden onset of facial and neck swelling was considered as an allergic reaction by the dentist and dexamethasone and antihistamines were applied. The majority of cases are self-limiting and benign. Surgical treatment is not 
necessary in cases with no complication, and most of the cases spontaneously recover with close followup. Our patient also recovered spontaneously without surgical intervention.

Complications that may develop after dental procedures may not be limited to oral cavity and head-neck region. It should be kept in mind that the use of high-speed air turbine drill and air spraying devices in dental applications may cause serious complications such as PM and mediastinitis. Clinicians are advised to question the devices used for tooth extraction in patients that present with head and neck swelling after dental procedures.

\section{Declaration of conflicting interests}

The authors declared no conflicts of interest with respect to the authorship and/or publication of this article.

\section{Funding}

The authors received no financial support for the research and/or authorship of this article.

\section{REFERENCES}

1. Sapmaz E, Işık H, Doğan D, Kavaklı K, Çaylak H. A comparative study of pneumomediastinums based on clinical experience. Ulus Travma Acil Cerrahi Derg 2019;25:497-502.

2. Erol G, Kubat E, Sicim H, Kadan M, Bolcal C. An unexpected complication of robotic cardiac surgery: Pneumomediastinum. J Saudi Heart Assoc 2019;31:106-8.

3. Durukan P, Salt O, Ozkan S, Durukan B, Kavalci C. Cervicofacial emphysema and pneumomediastinum after a high-speed air drill endodontic treatment procedure. Am J Emerg Med 2012;30:2095.e3-6.

4. Yang SC, Chiu TH, Lin TJ, Chan HM. Subcutaneous emphysema and pneumomediastinum secondary to dental extraction: a case report and literature review. Kaohsiung J Med Sci 2006;22:641-5.

5. Nishimura T, Sawai T, Kadoi K, Yamada T, Yoshie N, Ueda $\mathrm{T}$, et al. Iatrogenic subcutaneous emphysema and pneumomediastinum following a high-speed air drill dental treatment procedure. Acute Med Surg 2015;2:253-6.

6. Ocakcioglu I, Koyuncu S, Kupeli M, Bol O. Pneumomediastinum after Tooth Extraction. Case Rep Surg 2016;2016:4769180. 